\title{
Informing COVID-19 vaccination priorities based on the prevalence of risk factors among adults in Canada
}

\author{
Finlay A. McAlister MD MSc, Tracey Bushnik MBA, Alexander A. Leung MD MPH, Lynora Saxinger MD
}

Cite as: CMAJ 2021 April 26;193:E617-21. doi: 10.1503/cmaj.210529; early-released April 9, 2021

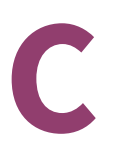

oncern about imbalances between the demand and the supply of vaccinations for severe acute respiratory syndrome coronavirus 2 (SARS-CoV-2) have been raised, given worldwide demand, centralized manufacturing and limitations in the infrastructure for vaccine delivery and administration in Canada. The optimal strategy for vaccination allocation to maximize public health benefit in Canada is unclear. The first phase of Canada's vaccine rollout focused on those at the highest risk for being infected with or transmitting SARS-CoV-2, including long-term care residents and staff, older adults, adults in Indigenous communities and front-line health care workers. ${ }^{1}$ However, debate continues about whether subsequent vaccinations (stages 2 and 3 in the National Advisory Committee on Immunization [NACI] schema $)^{2}$ should be prioritized solely on the basis of age (as age is the strongest risk factor for poor outcomes from coronavirus disease 2019 [COVID-19]), or whether a more complex rollout targeting those with other high-risk features (e.g., medical or exposure-related risk factors) may be preferable. ${ }^{3}$ Vaccine prioritization questions are also related to the debate on whether to delay second doses so that as many people as possible receive at least 1 dose. ${ }^{3,4}$ Substantial variability exists between the provinces and territories regarding current approaches to vaccination, with differing definitions of who qualifies as medically, geographically or occupationally "high risk."

To optimize vaccination strategies, we must first delineate what proportion of adults in Canada are at higher risk for severe outcomes if infected with SARS-CoV-2. A recent evaluation of data from the National Health and Nutrition Examination Survey (NHANES) reported that three-quarters of adults in the United States had 1 or more risk factors for severe COVID-19, as defined by the US Centers for Disease Control and Prevention (CDC). ${ }^{6}$ We analyze the burden of risk factors in the Canadian population to complement analyses of provincial administrative data sets to better inform ongoing SARS-CoV-2 vaccination prioritization in Canada.

\section{KEY POINTS}

- Debate continues about how best to prioritize vaccinations for SARS-CoV-2 once the most vulnerable older adults have been vaccinated.

- Although age is the most important risk factor for severe COVID19, three-quarters of adults in Canada have at least 1 other risk factor for severe illness, and one-third have 2 or more risk factors, based on analysis of national survey data.

- A more nuanced approach to vaccine prioritization that takes into account the prevalence and weight of risk factors, as well as geographic and occupational risk exposures is needed.

- Continued adherence to public health advice for universal masking, physical distancing and frequent hand washing will be necessary as vaccination programs proceed, given the high prevalence of risk factors in the Canadian population.

- Policies that allow a prolonged interval between first and second vaccine doses as a means of maximizing the number of people who will receive at least 1 dose of vaccine as quickly as possible also make sense, given a high burden of risk factors, as long as first-dose protection data remain favourable.

\section{How common are risk factors for severe COVID-19 infection among community- dwelling adults in Canada?}

Although each Canadian province and territory can evaluate their administrative health data to identify the proportion of their population at risk for severe COVID-19, there are limitations to using such data to estimate disease frequencies, as they often underestimate the burden of chronic diseases that are predominantly managed in outpatient settings. ${ }^{7,8}$ Moreover, some risk factors for severe COVID-19 (e.g., smoking, obesity, ethnicity $)^{9-14}$ are not captured at all. Therefore, we estimated the prevalence of risk factors for severe COVID-19 in communitydwelling adults in Canada from 2 population-based surveys, the Canadian Community Health Survey (CCHS) ${ }^{15} 2019$ and the 
Canadian Health Measures Survey $(\mathrm{CHMS})^{16}$ 2016-2019. We defined risk factors for severe COVID-19 using the QCOVID living risk prediction algorithm, derived from 8.2 million adults in England. ${ }^{10}$ The QCOVID algorithm includes all of the risk factors for more severe COVID-19 that were identified by the $\mathrm{CDC}^{6}$ and in a rapid review ${ }^{11}$ conducted for the $\mathrm{NACl}$. Although the QCOVID calculator provides specific estimates of absolute risk for severe COVID-19 in individual patients based on their characteristics, the supporting study ${ }^{9}$ also provided sex-specific adjusted hazard ratios (HRs) for death or hospitalization with each risk factor (Table 1).
We used data from the CCHS and CHMS because they are population-based health surveys conducted by Statistics Canada in all jurisdictions, and are representative of $97 \%$ of the country's population. ${ }^{15,16}$ Although these surveys exclude people who are institutionalized, those living on reserves or in remote regions and full-time members of the Canadian Forces, these groups have already been addressed in current provincial and territorial vaccination plans. After excluding 462 pregnant people (to avoid erroneously including pregnancy-related conditions as risk factors), we analyzed data from 60742 adult respondents of the CCHS 2019 and from 6662 adult respondents

Table 1 (part 1 of 2): Weighted prevalence of risk factors for severe COVID-19 among adult respondents of the Canadian Community Health Survey 2019 in provincial Canada, by sex and age group

\begin{tabular}{|c|c|c|c|c|c|c|c|c|c|c|c|c|}
\hline \multirow[b]{2}{*}{ Risk factor } & \multicolumn{2}{|c|}{$18-49 \mathrm{yr}$} & \multicolumn{2}{|c|}{$50-59 \mathrm{yr}$} & \multicolumn{2}{|c|}{$60-69 \mathrm{yr}$} & \multicolumn{2}{|c|}{70 yr or older } & \multicolumn{2}{|c|}{ Overall } & \multicolumn{2}{|c|}{$\begin{array}{l}\text { Adjusted HR ( } 95 \% \\
\text { CI) for severe } \\
\text { COVID-19* }\end{array}$} \\
\hline & $\begin{array}{l}\text { Male, } \\
\%(95 \% \\
\text { CI) }\end{array}$ & $\begin{array}{l}\text { Female, } \\
\%(95 \% \\
\text { CI) }\end{array}$ & $\begin{array}{l}\text { Male, } \\
\%(95 \% \\
\text { CI) }\end{array}$ & $\begin{array}{l}\text { Female, } \\
\%(95 \% \\
\text { CI) }\end{array}$ & $\begin{array}{l}\text { Male, } \\
\%(95 \% \\
\text { CI) }\end{array}$ & $\begin{array}{l}\text { Female, } \\
\%(95 \% \\
\text { CI) }\end{array}$ & $\begin{array}{l}\text { Male, } \\
\%(95 \% \\
\text { CI) }\end{array}$ & $\begin{array}{l}\text { Female, } \\
\%(95 \% \\
\text { CI) }\end{array}$ & $\begin{array}{l}\text { Male, } \\
\%(95 \% \\
\text { CI) }\end{array}$ & $\begin{array}{l}\text { Female, } \\
\%(95 \% \\
\text { CI) }\end{array}$ & Male & Female \\
\hline $\begin{array}{l}\text { Household } \\
\text { income } \\
\text { (lowest } \\
\text { quintile)† }\end{array}$ & $\begin{array}{c}19.4 \\
(18.1- \\
20.7)\end{array}$ & $\begin{array}{c}23.1 \\
(21.8- \\
24.4)\end{array}$ & $\begin{array}{c}15.1 \\
(13.2- \\
17.3)\end{array}$ & $\begin{array}{c}14.9 \\
(13.2- \\
16.8)\end{array}$ & $\begin{array}{c}15.6 \\
(14.1- \\
17.2)\end{array}$ & $\begin{array}{c}20.2 \\
(18.4- \\
22.1)\end{array}$ & $\begin{array}{c}20.1 \\
(18.6- \\
21.8)\end{array}$ & $\begin{array}{c}29.4 \\
(27.7- \\
31.1)\end{array}$ & $\begin{array}{c}18.2 \\
(17.3- \\
19)\end{array}$ & $\begin{array}{c}22.2 \\
(21.4- \\
23.1)\end{array}$ & $\begin{array}{l}1.5 \\
(1.4- \\
1.6) ฯ\end{array}$ & $\begin{array}{l}1.5 \\
(1.4- \\
1.6) \uparrow\end{array}$ \\
\hline $\begin{array}{l}\text { Smoker (daily } \\
\text { or occasional) }\end{array}$ & $\begin{array}{c}20.7 \\
(19.6- \\
22.0)\end{array}$ & $\begin{array}{c}13.7 \\
(12.8- \\
14.6)\end{array}$ & $\begin{array}{c}21.0 \\
(19.1- \\
23.2)\end{array}$ & $\begin{array}{c}17.0 \\
(15.4- \\
18.7)\end{array}$ & $\begin{array}{c}17.1 \\
(15.6- \\
18.8)\end{array}$ & $\begin{array}{c}14.4 \\
(13.0- \\
15.9)\end{array}$ & $\begin{array}{c}7.6 \\
(6.7-8.6)\end{array}$ & $\begin{array}{c}5.9 \\
(5.3-6.7)\end{array}$ & $\begin{array}{c}18.5 \\
(17.7- \\
19.3)\end{array}$ & $\begin{array}{c}13.2 \\
(12.5- \\
13.8)\end{array}$ & \multicolumn{2}{|c|}{$\begin{array}{c}2.2 \\
(1.5-3.1) \text { if } 30 \text { pack } \\
\text { years or more (no } \\
\text { sex breakdown) }\end{array}$} \\
\hline $\begin{array}{l}\text { Diabetes } \\
\text { mellitus }\end{array}$ & $\begin{array}{c}2.9 \\
(2.4-3.5)\end{array}$ & $\begin{array}{c}1.7 \\
(1.3-2.1)\end{array}$ & $\begin{array}{c}11.7 \\
(10.0- \\
13.7)\end{array}$ & $\begin{array}{c}6.4 \\
(5.3-7.7)\end{array}$ & $\begin{array}{c}18.1 \\
(16.4- \\
19.9)\end{array}$ & $\begin{array}{c}12.0 \\
(10.7- \\
13.5)\end{array}$ & $\begin{array}{c}24.8 \\
(23.1- \\
26.5)\end{array}$ & $\begin{array}{c}16.5 \\
(15.1- \\
18.0)\end{array}$ & $\begin{array}{l}9.7 \\
(9.2- \\
10.3)\end{array}$ & $\begin{array}{c}6.5 \\
(6.0-6.9)\end{array}$ & $\begin{array}{c}2.7 \\
(2.4- \\
3.0)\end{array}$ & $\begin{array}{c}2.7 \\
(2.4-3.2)\end{array}$ \\
\hline \multicolumn{13}{|l|}{ Obesity } \\
\hline $\mathrm{BMI} \geq 30$ & $\begin{array}{c}19.4 \\
(18.3- \\
20.5)\end{array}$ & $\begin{array}{c}18.6 \\
(17.5- \\
19.8)\end{array}$ & $\begin{array}{c}27.8 \\
(25.5- \\
30.1)\end{array}$ & $\begin{array}{c}22.9 \\
(20.8- \\
25.2)\end{array}$ & $\begin{array}{c}25.5 \\
(23.7- \\
27.5)\end{array}$ & $\begin{array}{c}24.2 \\
(22.3- \\
26.1)\end{array}$ & $\begin{array}{c}18.7 \\
(17.3- \\
20.3)\end{array}$ & $\begin{array}{c}18.1 \\
(16.8- \\
19.5)\end{array}$ & $\begin{array}{c}21.7 \\
(20.9- \\
22.6)\end{array}$ & $\begin{array}{c}20.2 \\
(19.4- \\
21.0)\end{array}$ & \multicolumn{2}{|c|}{$\begin{array}{c}1.8 \\
(1.4-2.4)^{\star \star} \text { (no sex } \\
\text { breakdown) }\end{array}$} \\
\hline $\begin{array}{l}\text { BMI } 30 \text { to } \\
39.9\end{array}$ & $\begin{array}{c}17.3 \\
(16.2- \\
18.4)\end{array}$ & $\begin{array}{c}15.6 \\
(14.5- \\
16.6)\end{array}$ & $\begin{array}{c}25.9 \\
(23.7- \\
28.1)\end{array}$ & $\begin{array}{c}20.1 \\
(18.1- \\
22.3)\end{array}$ & $\begin{array}{c}24.1 \\
(22.3- \\
26.1)\end{array}$ & $\begin{array}{c}21.5 \\
(19.7- \\
23.4)\end{array}$ & $\begin{array}{c}17.9 \\
(16.5- \\
19.4)\end{array}$ & $\begin{array}{c}15.9 \\
(14.7- \\
17.3)\end{array}$ & $\begin{array}{c}19.9 \\
(19.2- \\
20.7)\end{array}$ & $\begin{array}{c}17.4 \\
(16.6- \\
18.1)\end{array}$ & \multicolumn{2}{|c|}{$\begin{array}{c}1.8 \\
\begin{array}{c}(1.5-2.2) \dagger \dagger \\
\text { breakdown) }\end{array}\end{array}$} \\
\hline $\mathrm{BMI} \geq 40$ & $\begin{array}{c}2.1 \\
(1.7-2.6)\end{array}$ & $\begin{array}{c}3.1 \\
(2.6-3.7)\end{array}$ & $\begin{array}{c}1.9 \\
(1.3- \\
2.7)\end{array}$ & $\begin{array}{c}2.8 \\
(2.2-3.6)\end{array}$ & $\begin{array}{c}1.4 \\
(1.0-1.9)\end{array}$ & $\begin{array}{c}2.7 \\
(2.0-3.5)\end{array}$ & $\begin{array}{c}0.8 \\
(0.6-1.2)\end{array}$ & $\begin{array}{c}2.1 \\
(1.7-2.7)\end{array}$ & $\begin{array}{c}1.8 \\
(1.5-2.1)\end{array}$ & $\begin{array}{c}2.8 \\
(2.5-3.2)\end{array}$ & \multicolumn{2}{|c|}{$\begin{array}{c}2.5 \\
\begin{array}{c}(1.8-3.4) \dagger \dagger \\
\text { breakdown) }\end{array}\end{array}$} \\
\hline Heart disease & $\begin{array}{c}0.8 \\
(0.6-1.1)\end{array}$ & $\begin{array}{c}0.7 \\
(0.5-1.0)\end{array}$ & $\begin{array}{c}5.6 \\
(4.5- \\
6.9)\end{array}$ & $\begin{array}{c}2.6 \\
(2.0-3.3)\end{array}$ & $\begin{array}{c}11.7 \\
(10.3- \\
13.3)\end{array}$ & $\begin{array}{c}5.3 \\
(4.5-6.3)\end{array}$ & $\begin{array}{c}20.6 \\
(19.1- \\
22.2)\end{array}$ & $\begin{array}{c}13.6 \\
(12.5- \\
14.7)\end{array}$ & $\begin{array}{c}6.0 \\
(5.6-6.4)\end{array}$ & $\begin{array}{c}3.8 \\
(3.5-4.1)\end{array}$ & $\begin{array}{c}1.2 \\
(1.1- \\
1.3)\end{array}$ & $\begin{array}{c}1.3 \\
(1.2-1.4)\end{array}$ \\
\hline COPD $\ddagger$ & $\begin{array}{c}1.5 \\
(1.0-2.3)\end{array}$ & $\begin{array}{c}1.0 \\
(0.7-1.4)\end{array}$ & $\begin{array}{c}2.8 \\
(2.2- \\
3.6)\end{array}$ & $\begin{array}{c}3.1 \\
(2.5-3.8)\end{array}$ & $\begin{array}{c}5.8 \\
(4.7-7.1)\end{array}$ & $\begin{array}{c}5.9 \\
(5.1-6.9)\end{array}$ & $\begin{array}{c}7.8 \\
(6.9-8.7)\end{array}$ & $\begin{array}{c}8.0 \\
(7.2-8.8)\end{array}$ & $\begin{array}{c}3.9 \\
(3.5-4.4)\end{array}$ & $\begin{array}{c}4.1 \\
(3.8-4.4)\end{array}$ & $\begin{array}{c}1.3 \\
(1.2- \\
1.4)\end{array}$ & $\begin{array}{c}1.3 \\
(1.2-1.4)\end{array}$ \\
\hline Asthma & $\begin{array}{c}6.6 \\
(5.9-7.4)\end{array}$ & $\begin{array}{l}9.4 \\
(8.6- \\
10.2)\end{array}$ & $\begin{array}{c}6.2 \\
(5.2- \\
7.5)\end{array}$ & $\begin{array}{c}8.4 \\
(7.2-9.8)\end{array}$ & $\begin{array}{c}5.7 \\
(4.9-6.7)\end{array}$ & $\begin{array}{l}10.0 \\
(8.8- \\
11.3)\end{array}$ & $\begin{array}{c}5.9 \\
(5.1-6.8)\end{array}$ & $\begin{array}{c}8.0 \\
(7.1-8.9)\end{array}$ & $\begin{array}{c}6.3 \\
(5.8-6.8)\end{array}$ & $\begin{array}{c}9.1 \\
(8.6-9.6)\end{array}$ & $\begin{array}{c}1.1 \\
(1.0- \\
1.1)\end{array}$ & $\begin{array}{c}1.0 \\
(1.0-1.1)\end{array}$ \\
\hline Stroke & $\begin{array}{c}0.2 \\
(0.1-0.3)\end{array}$ & $\begin{array}{c}0.3 \\
(0.2-0.5)\end{array}$ & $\begin{array}{c}1.5 \\
(0.9- \\
2.4)\end{array}$ & $\begin{array}{c}0.7 \\
(0.4-1.1)\end{array}$ & $\begin{array}{c}2.6 \\
(2.0-3.3)\end{array}$ & $\begin{array}{c}1.9 \\
(1.4-2.6)\end{array}$ & $\begin{array}{c}5.3 \\
(4.6-6.2)\end{array}$ & $\begin{array}{c}4.2 \\
(3.5-5.0)\end{array}$ & $\begin{array}{c}1.5 \\
(1.3-1.7)\end{array}$ & $\begin{array}{c}1.3 \\
(1.1-1.4)\end{array}$ & $\begin{array}{c}1.3 \\
(1.2- \\
1.4)\end{array}$ & $\begin{array}{c}1.4 \\
(1.3-1.5)\end{array}$ \\
\hline Hypertension & $\begin{array}{c}7.3 \\
(6.5-8.1)\end{array}$ & $\begin{array}{c}5.4 \\
(4.8-6.1)\end{array}$ & $\begin{array}{c}28.0 \\
(25.7- \\
30.4)\end{array}$ & $\begin{array}{c}21.0 \\
(18.9- \\
23.2)\end{array}$ & $\begin{array}{c}44.0 \\
(41.9- \\
46.1)\end{array}$ & $\begin{array}{c}35.1 \\
(33.1- \\
37.1)\end{array}$ & $\begin{array}{c}56.4 \\
(54.4- \\
58.4)\end{array}$ & $\begin{array}{c}58.2 \\
(56.4- \\
59.9)\end{array}$ & $\begin{array}{c}23.1 \\
(22.4- \\
23.8)\end{array}$ & $\begin{array}{c}21.1 \\
(20.4- \\
21.8)\end{array}$ & \multicolumn{2}{|c|}{$\begin{array}{c}2.1 \\
\begin{array}{c}(1.7-2.5) \ddagger \ddagger \text { (no sex } \\
\text { breakdown) }\end{array}\end{array}$} \\
\hline $\begin{array}{l}\text { Cancer (any } \\
\text { type active) }\end{array}$ & $\begin{array}{c}0.3 \\
(0.2-0.5)\end{array}$ & $\begin{array}{c}0.3 \\
(0.2-0.5)\end{array}$ & $\begin{array}{c}1.1 \\
(0.8- \\
1.5)\end{array}$ & $\begin{array}{c}1.4 \\
(1.0-2.1)\end{array}$ & $\begin{array}{c}3.7 \\
(2.8-4.7)\end{array}$ & $\begin{array}{c}2.5 \\
(2.0-3.3)\end{array}$ & $\begin{array}{c}7.7 \\
(6.7-8.7)\end{array}$ & $\begin{array}{c}3.9 \\
(3.3-4.5)\end{array}$ & $\begin{array}{c}1.9 \\
(1.7-2.2)\end{array}$ & $\begin{array}{c}1.4 \\
(1.3-1.6)\end{array}$ & $\begin{array}{c}1.4 \\
(1.1- \\
1.7)\end{array}$ & $\begin{array}{c}1.6 \\
(1.2-1.9)\end{array}$ \\
\hline Dementia§ & $\mathrm{F}$ & $\mathrm{F}$ & $\mathrm{F}$ & $\mathrm{F}$ & $\begin{array}{c}0.8 \\
(0.4-1.6)\end{array}$ & $\begin{array}{c}0.6 \\
(0.3-1.1)\end{array}$ & $\begin{array}{c}2.9 \\
(2.3-3.7)\end{array}$ & $\begin{array}{c}3.3 \\
(2.6-4.2)\end{array}$ & $\begin{array}{c}0.9 \\
(0.7-1.2)\end{array}$ & $\begin{array}{c}1.0 \\
(0.8-1.2)\end{array}$ & $\begin{array}{c}2.7 \\
(2.5- \\
2.9)\end{array}$ & $\begin{array}{c}2.3 \\
(2.1-2.5)\end{array}$ \\
\hline
\end{tabular}


Table 1 (part 2 of 2): Weighted prevalence of risk factors for severe COVID-19 among adult respondents of the Canadian Community Health Survey 2019 in provincial Canada, by sex and age group

\begin{tabular}{|c|c|c|c|c|c|c|c|c|c|c|c|c|}
\hline \multirow[b]{2}{*}{ Risk factor } & \multicolumn{2}{|c|}{$18-49 \mathrm{yr}$} & \multicolumn{2}{|c|}{$50-59 \mathrm{yr}$} & \multicolumn{2}{|c|}{$60-69 \mathrm{yr}$} & \multicolumn{2}{|c|}{70 yr or older } & \multicolumn{2}{|c|}{ Overall } & \multicolumn{2}{|c|}{$\begin{array}{l}\text { Adjusted HR (95\% } \\
\text { CI) for severe } \\
\text { COVID-19* }\end{array}$} \\
\hline & $\begin{array}{l}\text { Male, } \\
\%(95 \% \\
\text { CI) }\end{array}$ & $\begin{array}{l}\text { Female, } \\
\%(95 \% \\
\text { CI) }\end{array}$ & $\begin{array}{l}\text { Male, } \\
\%(95 \% \\
\text { CI) }\end{array}$ & $\begin{array}{l}\text { Female, } \\
\%(95 \% \\
\text { CI) }\end{array}$ & $\begin{array}{l}\text { Male, } \\
\%(95 \% \\
\text { CI) }\end{array}$ & $\begin{array}{l}\text { Female, } \\
\%(95 \% \\
\text { CI) }\end{array}$ & $\begin{array}{l}\text { Male, } \\
\%(95 \% \\
\text { CI) }\end{array}$ & $\begin{array}{l}\text { Female, } \\
\%(95 \% \\
\text { CI) }\end{array}$ & $\begin{array}{l}\text { Male, } \\
\%(95 \% \\
\text { CI) }\end{array}$ & $\begin{array}{l}\text { Female, } \\
\%(95 \% \\
\text { CI) }\end{array}$ & Male & Female \\
\hline \multicolumn{13}{|l|}{ Ethnicity } \\
\hline White & $\begin{array}{c}65.4 \\
(63.8- \\
67.0)\end{array}$ & $\begin{array}{c}63.7 \\
(62.2- \\
65.2)\end{array}$ & $\begin{array}{c}77.1 \\
(74.7- \\
79.3)\end{array}$ & $\begin{array}{c}77.0 \\
(74.6- \\
79.1)\end{array}$ & $\begin{array}{c}83.1 \\
(81.0- \\
85.1)\end{array}$ & $\begin{array}{c}85.0 \\
(83.3- \\
86.6)\end{array}$ & $\begin{array}{c}85.8 \\
(84.3- \\
87.2)\end{array}$ & $\begin{array}{c}87.8 \\
(86.3- \\
89.1)\end{array}$ & $\begin{array}{c}72.9 \\
(71.8- \\
73.9)\end{array}$ & $\begin{array}{c}73.2 \\
(72.2- \\
74.1)\end{array}$ & $\begin{array}{c}1.0 \\
(1.0- \\
1.0)\end{array}$ & $\begin{array}{c}1.0 \\
(1.0-1.0)\end{array}$ \\
\hline South Asian & $\begin{array}{c}7.2 \\
(6.3-8.1)\end{array}$ & $\begin{array}{c}6.7 \\
(5.9-7.7)\end{array}$ & $\begin{array}{c}4.7 \\
(3.4- \\
6.4)\end{array}$ & $\begin{array}{c}3.6 \\
(2.5-5.3)\end{array}$ & $\begin{array}{c}3.5 \\
(2.4-5.0)\end{array}$ & $\begin{array}{c}1.4 \\
(0.9-2.1)\end{array}$ & $\begin{array}{c}3.9 \\
(2.9-5.2)\end{array}$ & $\begin{array}{c}1.5 \\
(1.0-2.1)\end{array}$ & $\begin{array}{c}5.7 \\
(5.1-6.4)\end{array}$ & $\begin{array}{c}4.5 \\
(4.0-5.1)\end{array}$ & $\begin{array}{c}2.0 \\
(1.8- \\
2.3)\end{array}$ & $\begin{array}{c}1.9 \\
(1.6-2.2)\end{array}$ \\
\hline Other Asian & $\begin{array}{c}10.2 \\
(9.2-11.3)\end{array}$ & $\begin{array}{c}11.8 \\
(10.8- \\
13)\end{array}$ & $\begin{array}{c}7.3 \\
(6.0- \\
9.0)\end{array}$ & $\begin{array}{c}7.5 \\
(6.1-9.3)\end{array}$ & $\begin{array}{c}6.0 \\
(4.9-7.5)\end{array}$ & $\begin{array}{c}5.5 \\
(4.6-6.7)\end{array}$ & $\begin{array}{c}4.2 \\
(3.5-5.1)\end{array}$ & $\begin{array}{c}4.6 \\
(3.7-5.8)\end{array}$ & $\begin{array}{c}8.3 \\
(7.6-9.0)\end{array}$ & $\begin{array}{c}9.0 \\
(8.3-9.7)\end{array}$ & $\begin{array}{c}2.2 \\
(1.8- \\
2.6)\end{array}$ & $\begin{array}{c}2.0 \\
(1.6-2.5)\end{array}$ \\
\hline Black & $\begin{array}{c}3.8 \\
(3.1-4.6)\end{array}$ & $\begin{array}{c}4.3 \\
(3.7-5.0)\end{array}$ & $\begin{array}{c}2.7 \\
(1.8- \\
3.9)\end{array}$ & $\begin{array}{c}1.9 \\
(1.3-2.9)\end{array}$ & $\begin{array}{c}1.0 \\
(0.7-1.6)\end{array}$ & $\begin{array}{c}1.8 \\
(1.2-2.6)\end{array}$ & $\begin{array}{c}0.9 \\
(0.6-1.3)\end{array}$ & $\begin{array}{c}1.8 \\
(1.3-2.6)\end{array}$ & $\begin{array}{c}2.8 \\
(2.4-3.3)\end{array}$ & $\begin{array}{c}3.1 \\
(2.7-3.5)\end{array}$ & $\begin{array}{c}2.6 \\
(2.3- \\
3.0)\end{array}$ & $\begin{array}{c}2.3 \\
(2.0-2.6)\end{array}$ \\
\hline $\begin{array}{l}\text { Indigenous } \\
\text { identity }\end{array}$ & $\begin{array}{c}4.0 \\
(3.6-4.6)\end{array}$ & $\begin{array}{c}4.0 \\
(3.6-4.5)\end{array}$ & $\begin{array}{c}3.3 \\
(2.7- \\
4.1)\end{array}$ & $\begin{array}{c}4.1 \\
(3.3-5.0)\end{array}$ & $\begin{array}{c}3.1 \\
(2.3-4.1)\end{array}$ & $\begin{array}{c}2.7 \\
(2.2-3.3)\end{array}$ & $\begin{array}{c}1.6 \\
(1.3-2.1)\end{array}$ & $\begin{array}{c}1.4 \\
(1.2-1.7)\end{array}$ & $\begin{array}{c}3.4 \\
(3.1-3.8)\end{array}$ & $\begin{array}{c}3.4 \\
(3.1-3.7)\end{array}$ & $\begin{array}{l}(2.2-2 \\
\text { bre }\end{array}$ & $\begin{array}{l}\text { no sex } \\
\text { lown }\end{array}$ \\
\hline Other & $\begin{array}{c}9.4 \\
(8.4-10.4)\end{array}$ & $\begin{array}{c}9.4 \\
(8.5- \\
10.4)\end{array}$ & $\begin{array}{c}5.0 \\
(3.9- \\
6.3)\end{array}$ & $\begin{array}{c}5.9 \\
(4.6-7.5)\end{array}$ & $\begin{array}{c}3.2 \\
(2.5-4.2)\end{array}$ & $\begin{array}{c}3.7 \\
(2.8-4.9)\end{array}$ & $\begin{array}{c}3.6 \\
(2.9-4.5)\end{array}$ & $\begin{array}{c}2.9 \\
(2.1-3.9)\end{array}$ & $\begin{array}{c}6.9 \\
(6.3-7.5)\end{array}$ & $\begin{array}{c}6.8 \\
(6.3-7.4)\end{array}$ & $\begin{array}{c}2.1 \\
(1.8- \\
2.4)\end{array}$ & $\begin{array}{c}1.9 \\
(1.6-2.2)\end{array}$ \\
\hline
\end{tabular}

Note: $\mathrm{BMI}=$ body mass index, $\mathrm{Cl}=$ confidence interval, $\mathrm{COPD}=$ chronic obstructive pulmonary disease, $\mathrm{COVID}-19=$ coronavirus disease $2019, \mathrm{~F}=$ estimate suppressed because of insufficient sample size, $\mathrm{HR}=$ hazard ratio.

*Adjusted HR for severe COVID-19 (death or hospitalization) largely derived from the supplementary figures in the QCOVID report (note that in QCOVID, heart disease = coronary disease, atrial fibrillation, or heart failure; cancer = blood cancer or respiratory tract cancer; and we report the adjusted HR for type 2 DM). ${ }^{9}$ Relative risk for death or hospitalization in Indigenous versus non-Indigenous people in Alberta from personal communication (Ting Wang, Alberta SPOR Support Unit Data Platform, April 5, 2021).

tHousehold income, lowest quintile is based on the the adjusted ratio of total household income to the low income cut-off corresponding to household and community size.

$\ddagger$ Asked of persons aged 35 or older.

$\S$ Asked of persons aged 41 or older.

ISocioeconomic status in QCOVID reported as increased risk per 5 unit increment in the Townsend material deprivation score.

${ }^{\star \star}$ Systematic review of 22 studies. ${ }^{12}$

††From New York cohort. ${ }^{14}$

‡\$Systematic review of 23 studies. ${ }^{13}$

of the CHMS 2016-2019 (see Appendix 1, available at www.cmaj. ca/lookup/doi/10.1503/cmaj.210529/tab-related-content, for detailed methods).

A full list of the relevant risk factors included in the CCHS is provided in Table 1. Across provinces, the most common risk factors were hypertension ( $23.1 \%$ of men and $21.1 \%$ of women) and obesity ( $21.7 \%$ of men and $20.2 \%$ of women). About $27 \%$ of men and women were racialized, and $3.4 \%$ self-identified as First Nations, Métis or Inuit. Chronic liver and renal disease (with adjusted HR in the QCOVID analysis ranging from 1.2 to 6.7 , depending on severity) are not assessed in the CCHS, but less than $3 \%$ of CHMS respondents reported having either condition. As it is not possible to link data from the CCHS and CHMS, we could not determine how many of these people also had the CCHS comorbidities of interest.

Thus, among community-dwelling people in Canada, $74.0 \%$ of men and $70.9 \%$ of women reported having at least 1 risk factor for severe COVID-19, and $39.3 \%$ and $36.3 \%$, respectively, had at least 2 risk factors (Table 1 and Appendix 2, available at www.cmaj.ca/ lookup/doi/10.1503/cmaj.210529/tab-related-content). Although the proportion of Canadians with risk factors (particularly multiple risk factors) increased across the age strata, it is important to note that even among adults aged $18-49$ years, $70.9 \%$ of men and $67.9 \%$ of women had at least 1 risk factor and $31 \%$ had at least 2 risk factors for severe COVID-19.

The frequencies of all risk factors were more common in men than women, except chronic obstructive pulmonary disease, asthma and low income status (Table 1). Although the focus of our analysis is on estimates for Canada as a whole, a more detailed provincial breakdown based on the CCHS 2017/18 is available directly from Statistics Canada. ${ }^{17}$

\section{What are the limitations of using the CCHS and CHMS to evaluate risk factors for COVID-19?}

Although the CCHS and CHMS are nationally representative, population-based health surveys, there are some limitations to using them to estimate risk factors for severe COVID-19. For example, the risk factor frequencies we report are conservative, selfreported underestimates that miss undiagnosed chronic illnesses. We were also unable to report data for some rare but important risk factors for severe COVID-19 that were not included in either survey, such as Down syndrome (adjusted HR for severe COVID-19 
in the QCOVID study 9.6 in men and 7.5 in women), sickle cell disease (adjusted HR 4.5 in men and 6.8 in women), neuromuscular diseases (adjusted HR 3.0 in men and 2.4 in women), recent bone marrow or stem cell transplants (adjusted HR 1.7 in men and 1.6 in women) or current chemotherapy (adjusted HR ranging from 1.74.3 in men and $2.1-15.0$ in women, depending on regimen). ${ }^{9}$

Although several studies ${ }^{9,11}$ have suggested that racialized minorities are at higher risk for severe COVID-19 illness, interpretation of whether or not that increased risk is because of biological factors is confounded by their interplay with the social determinants of health. As neither the CCHS or CHMS included people living on reserves, and estimates for the territories were not available for a single year of the CCHS, our data underestimate people of First Nations, Métis and Inuit identity. Moreover, neither survey collected information on working conditions (for example, whether people were essential workers or worked in close contact environments). Finally, both surveys excluded people experiencing homelessness and those in long-term care facilities or prisons; living in these situations is also a risk factor for severe COVID-19, ${ }^{18}$ but these groups have already been prioritized in the $\mathrm{NACl}$ vaccine guidance.

\section{How should Canada's rollout of SARS-CoV-2 vaccinations proceed?}

Given that population-based data show that nearly threequarters of Canadian adults have at least 1 risk factor for severe COVID-19 and more than one-third have 2 or more risk factors (mirroring the analysis of US NHANES data), ${ }^{6}$ a vaccination strategy cannot be based solely on age and the presence of a medical risk factor. If a risk-based strategic rollout is preferred because of external limits to speed, policy-makers may need to weigh the strength of each risk factor (from international risk studies such as QCOVID) ${ }^{9-14}$ with local prevalence data on risk factors (which will differ according to demographics and socioeconomic factors) and exposure risks (such as occupational or geographic transmission rates). Our analysis provides complementary information to administrative health data for policy-makers trying to weigh options for strategic vaccine allocation.

Internationally, the exemplar for a rapid, simple program is Israel (with 115 doses/100 persons administered as of Mar. 30, 2021) and the exemplar for a more complex risk-based rollout is the United Kingdom (with 51 doses/100 population). ${ }^{19}$ As of Mar. 30, 2021, $61 \%$ of people in Israel had received their first vaccine dose and $55 \%$ had been completely vaccinated; $45 \%$ of people in the UK had received their first vaccine dose and $6 \%$ had been completely vaccinated. ${ }^{19}$ The mass vaccination campaign in Israel initially targeted people older than 60 years, then expanded to all adults. In contrast, in the UK, ongoing rollout is by risk strata (identified by QCOVID scoring and age bands). In Canada, the current approach varies widely, from mass vaccination of adults by community without risk factor stratification in the territories, to more complex matrices of prioritization, variably including work setting, chronic medical conditions (with differing definitions and methods of operationalization across provinces) and neighbourhood or community transmission risk.
Our analysis, showing that most Canadians have 1 or more risk factors for severe COVID-19, supports arguments to prolong the interval between the first and second vaccine doses to withhold fewer doses and thereby maximize the number of people who will receive at least 1 dose of vaccine as quickly as possible, as long as evidence continues to support high rates of first-dose protection. ${ }^{4}$ A recently published decision analysis in the US suggested that $23 \%-32 \%$ of COVID-19 cases could be averted using a single dose rollout strategy, rather than conserving $50 \%$ of the vaccine supply for a second dose in 3-4 weeks. ${ }^{20}$ Another modelling study confirmed this assumption held even if the efficacy of a single dose was as low as 55\%. ${ }^{21}$ Encouragingly, preliminary data suggest that real-world effectiveness of a single vaccine dose may be in the order of $80 \% .{ }^{22-25}$ Emerging evidence ${ }^{26}$ also suggests that, for most people, immunogenicity after a first vaccine dose is sufficient to justify longer intervals before the second dose. The emergence of variants of concern driving a third wave of the pandemic also argues for offering rapid first-dose protection across the population, with ongoing monitoring of first-dose effectiveness. ${ }^{4}$ Thus, the UK instituted a delayed second dose approach on Dec. 30, 2020, and NACI followed suit on Mar. 1, 2021; the CDC began permitting a delay of up to 6 weeks for second doses of mRNA vaccines on Jan. 21, 2021. One caveat to this approach is that data around the durability of first-dose protection are lacking for some subgroups, such as older adults, people who are immunocompromised or patients with cancer, ${ }^{27}$ given concerns that prolonged viral replication in immunocompromised hosts may promote the emergence of more SARS-CoV-2 variants. ${ }^{28}$

Our analysis not only informs Canadians wondering how many others are in the same risk stratum as they, but also serves to emphasize the importance of continuing to follow public health advice such as universal masking, physical distancing and frequent hand washing as vaccination programs proceed, given that most adults in Canada have at least 1 risk factor for severe COVID-19.

\section{Conclusion}

Optimized SARS-CoV-2 vaccine rollout is crucial to avoiding unnecessary morbidity and death from COVID-19, and current plans are under tremendous scrutiny. Both internationally and in Canada, judgments are being made to balance potential rollout speed with the complexity and potential challenges of operationalizing a riskbased strategy. Our analysis of national, population-based survey data suggests that using risk factors for severe COVID-19 in a strategic vaccination strategy may not offer much refinement because of how widespread these conditions are. More detailed weighting of medical, geographic and occupational risks might be required if vaccination is constrained. In particular, since the third wave of the COVID-19 pandemic appears to be disproportionately affecting essential workers in economically disadvantaged neighbourhoods, weighting of such risks may be necessary for equity goals to be met. ${ }^{29}$ Vaccine prioritization is a question of ethics, as well as science. As such, we suggest that transparency in decision-making is important, especially where decisions vary across jurisdictions, to confirm that the rationale for decisions is driven by data and concordant with the shared values of local populations. 


\section{References}

1. Ismail SJ, Zhao L, Tunis MC, et al.; National Advisory Committee on Immunization. Key populations for early COVID-19 immunization: preliminary guidance for policy. CMAJ 2020;192:E1620-32.

2. National Advisory Committee on Immunization. Recommendations on the use of COVID-19 vaccines. Ottawa: Government of Canada; 2021. Available: www.canada.ca/en/public-health/services/immunization/national-advisory -committee-on-immunization-naci/recommendations-use-covid-19-vaccines. html (accessed 2021 Mar. 30).

3. Bubar KM, Reinholt K, Kissler SM, et al. Model-informed COVID-19 vaccine prioritization strategies by age and serostatus. Science 2021;371:916-21.

4. Kadire SR, Wachter RM, Lurie N. Delayed second dose versus standard regimen for COVID-19 vaccination. N Engl J Med 2021;384:e28.

5. Vaccines for COVID-19: How to get vaccinated or register. Ottawa: Government of Canada; 2021. Available: www.canada.ca/en/public-health/services/diseases/ coronavirus-disease-covid-19/vaccines/how-vaccinated.html\#a5 (accessed 2021 Apr. 7).

6. Li HL, Cheung BMY. The proportion of adult Americans at risk of severe COVID19 illness. J Gen Intern Med 2021;36:259-61.

7. Manuel DG, Rosella LC, Stukel TA. Importance of accurately identifying disease in studies using electronic health records. BMJ 2010;341:c4226.

8. McAlister FA, Tonelli M, Wiebe N, et al. The ecology of medical care for adults in Alberta, 2002/03 to 2016/17: a retrospective cohort study. CMAJ Open 2020;8:E169-77.

9. Clift $A K$, Coupland $\mathrm{CAC}, \mathrm{Keogh} \mathrm{RH}$, et al. Living risk prediction algorithm (QCOVID) for risk of hospital admission and mortality from coronavirus 19 in adults: national derivation and validation study. BMJ 2020;371:m3731.

10. Lowe KE, Zein J, Hatipoglu U, et al. Association of smoking and cumulative pack-year exposure with COVID-19 outcomes in the Cleveland Clinic COVID-19 Registry. JAMA Intern Med 2021 Jan. 25 [Epub ahead of print]. doi: 10.1001/ jamainternmed.2020.8360.

11. Wingert A, Pillay J, Gates M, et al. Risk factors for severe outcomes of COVID-19: a rapid review. medRxiv 2020 Sept. 1. doi: 10.1101/2020.08.27.201834344.

12. Chu Y, Yang J, Shi J, et al. Obesity is associated with increased severity of disease in COVID-19 pneumonia: a systematic review and meta-analysis. Eur $J$ Med Res 2020;25:64.

13. Fang X, Li S, Yu H, et al. Epidemiological, comorbidity factors with severity and prognosis of COVID-19: a systematic review and meta-analysis. Aging (Albany NY) 2020;12:12493-503.

14. Petrilli CM, Jones SA, Yang J, et al. Factors associated with hospital admission and critical illness among 5279 people with coronavirus disease 2019 in New York City: prospective cohort study. BMJ 2020;369:m1966.

15. Canadian Community Health Survey - Annual Component (CCHS). Ottawa: Statistics Canada; modified 2019 Nov. 18. Available: www23.statcan.gc.ca/ imdb/p2SV.pl?Function=getSurvey\&ld=1208978 (accessed 2021 Mar. 14).
16. Canadian Health Measures Survey (CHMS). Ottawa: Statistics Canada; modified 2019 Dec. 4. Available: www23.statcan.gc.ca/imdb/p2SV. pl?Function=getSurvey\&SDDS=5071 (accessed 2021 Mar. 14).

17. Table 13-10-0777-01 Number and percentage of adults (aged 18 years and older) in the household population with underlying health conditions, by age and sex (two-year period). Ottawa: Statistics Canada; 2021. Available: www150.statcan. gc.ca/t1/tbl1/en/tv.action?pid=1310077701 (accessed 2021 Apr. 7).

18. Richard L, Booth R, Rayner J, et al. Testing, infection and complication rates of COVID-19 among people with a recent history of homelessness in Ontario, Canada: a retrospective cohort study. CMAJ Open 2021;9:E1-9.

19. Roser M, Ritchie H, Ortiz-Ospina E, et al. Coronavirus (COVID-19) vaccinations. Oxford: Our World in Data; 2021. Available: https://ourworldindata.org/covid -vaccinations (accessed 2021 Mar. 30).

20. Tuite AR, Zhu L, Fisman DN, et al. Alternative dose allocation strategies to increase benefits from constrained COVID-19 vaccine supply. Ann Intern Med 2021 Jan. 5 [Epub ahead of print]. doi: 10.7326/M20-8137.

21. Paltiel AD, Zheng A, Schwartz JL. Speed versus efficacy: quantifying potential tradeoffs in COVID-19 vaccine deployment. Ann Intern Med 2021 Jan. 5 [Epub ahead of print]. doi: 10.7326/M20-7866.

22. Torjesen I. COVID-19: first doses of vaccines in Scotland led to a substantial fall in hospital admissions. BMJ 2021;372:n523.

23. Iacobucci G. COVID-19: Single dose of Pfizer and Oxford vaccines cuts risk of hospital admission by $80 \%$ in over 80s, data suggest. BMJ 2021;372:n612.

24. Rinott E, Youngster I, Lewis YE. Reduction in COVID-19 patients requiring mechanical ventilation following implementation of a national COVID-19 vaccination program: Israel, December 2020-February 2021. MMWR Morb Mortal Wkly Rep 2021;70:326-8.

25. Thompson MG, Burgess JL, Naleway AL, et al. Interim estimates of vaccine effectiveness of BNT162b2 and mRNA-1273 COVID-19 vaccines in preventing SARS-CoV-2 infection among health care personnel, first responders, and other essential and frontline workers: eight U.S. locations, December 2020March 2021. MMWR Morb Mortal Wkly Rep 2021;70:495-500.

26. Voysey M, Costa Clemens SA, Madhi SA, et al.; Oxford COVID Vaccine Trial Group. Single-dose administration and the influence of the timing of the booster dose on immunogenicity and efficacy of ChAdOx1 nCoV-19 (AZD1222) vaccine: a pooled analysis of four randomised trials [published erratum in Lancet 2021;397:880]. Lancet 2021;397:881-91.

27. Monin-Aldama L, Laing AG, Muñoz-Ruiz M, et al. Interim results of the safety and immune-efficacy of 1 versus 2 doses of COVID-19 vaccine BNT162b2 for cancer patients in the context of the UK vaccine priority guidelines. medRxiv 2021 Mar. 17. doi: 10.1101/2021.03.17.21253131.

28. Kemp SA, Collier DA, Datir RP, et al. SARS-CoV-2 evolution during treatment of chronic infection. Nature 2021 Feb. 5 [Epub ahead of print]. doi: 10.1038/s41586-021-03291-y.

29. Chagla Z, Ma H, Sander B, et al. Characterizing the disproportionate burden of SARS-CoV-2 variants of concern among essential workers in the Greater Toronto Area, Canada. medRxiv 2021 Mar. 26. doi: 10.1101/2021.03.22.21254127.
Competing interests: Lynora Saxinger is a member of Pandemic Planning Committee for Alberta Medical Association EZMSA (volunteer position) and reports being paid an honarium for a presentation on coronavirus disease 19 at a conference on virtual cancer care conference. No other competing interests were declared.

This article has been peer reviewed.

Affiliations: Department of Medicine (McAlister, Saxinger), Faculty of Medicine and Dentistry, University of Alberta, Edmonton, Alta.; Health Analysis Division (Bushnik), Statistics Canada, Ottawa, Ont.; Department of Medicine (Leung), Cumming School of Medicine, University of Calgary, Calgary, Alta.; Alberta Health Services (Saxinger), Edmonton, Alta.

Contributors: All of the authors contributed to the conception and design of the study. Tracey Bushnik acquired and analyzed the data, with supervision from Finlay McAlister, Alexander Leung and Lynora Saxinger. Finlay McAlister wrote the first draft of the manuscript, which all authors revised critically for intellectual content. All of the authors gave final approval of the version to be published and agreed to be accountable for all aspects of the work

Funding: Finlay McAlister holds the Alberta Health Services Chair in Cardiovascular Outcomes Research.

Content licence: This is an Open Access article distributed in accordance with the terms of the Creative Commons Attribution (CC BY-NC-ND 4.0) licence, which permits use, distribution and reproduction in any medium, provided that the original publication is properly cited, the use is noncommercial (i.e., research or educational use), and no modifications or adaptations are made. See: https://creativecommons.org/licenses/by-nc-nd/4.0/

Acknowledgement: The authors thank Ms. Ting Wang of the Alberta SPOR Support Unit for providing unpublished data on the relative rates of death or hospitalization in Indigenous v. non-Indigenous Albertans (April 5, 2021).

Correspondence to: Finlay McAlister, Finlay.McAlister@ualberta.ca 